Review

\title{
Craniofacial Osteomas: From Diagnosis to Therapy
}

\author{
Achille Tarsitano $^{1}\left(\mathbb{D}\right.$, Francesco Ricotta ${ }^{1}$, Paolo Spinnato ${ }^{2}\left(\mathbb{D}\right.$, Anna Maria Chiesa ${ }^{2}$, Maddalena Di Carlo ${ }^{2}$, \\ Anna Parmeggiani ${ }^{2, *}$, Marco Miceli ${ }^{2}$ and Giancarlo Facchini ${ }^{2}{ }^{\mathbb{D}}$ \\ 1 Maxillofacial Surgery Unit, IRCCS Policlinico di S. Orsola, 40138 Bologna, Italy; \\ achille.tarsitano2@unibo.it (A.T.); francesco.ricotta@aosp.bo.it (F.R.) \\ 2 Diagnostic and Interventional Radiology Unit, IRCCS Istituto Ortopedico Rizzoli, 40136 Bologna, Italy; \\ paolo.spinnato@ior.it (P.S.); annamaria.chiesa@ior.it (A.M.C.); maddalena.dicarlo@ior.it (M.D.C.); \\ marco.miceli@ior.it (M.M.); giancarlo.facchini@ior.it (G.F.) \\ * Correspondence: anna.parmeggiani2@studio.unibo.it; Tel.: +0039-05163-66273
}

check for updates

Citation: Tarsitano, A.; Ricotta, F.; Spinnato, P.; Chiesa, A.M.; Di Carlo, M.; Parmeggiani, A.; Miceli, M.; Facchini, G. Craniofacial Osteomas: From Diagnosis to Therapy. J. Clin. Med. 2021, 10, 5584. https://doi.org/ $10.3390 / \mathrm{jcm} 10235584$

Academic Editors: Carlo Masciocchi, Francesco Arrigoni and Anne Marie Kuijpers-Jagtman

Received: 15 October 2021

Accepted: 24 November 2021

Published: 27 November 2021

Publisher's Note: MDPI stays neutral with regard to jurisdictional claims in published maps and institutional affiliations.

Copyright: (c) 2021 by the authors. Licensee MDPI, Basel, Switzerland. This article is an open access article distributed under the terms and conditions of the Creative Commons Attribution (CC BY) license (https:/ / creativecommons.org/licenses/by/ $4.0 /)$.

\begin{abstract}
An osteoma is a benign bone lesion with no clear pathogenesis, almost exclusive to the craniofacial area. Osteomas show very slow continuous growth, even in adulthood, unlike other bony lesions. Since these lesions are frequently asymptomatic, the diagnosis is usually made by plain radiography or by a computed tomography (CT) scan performed for other reasons. Rarely, the extensive growth could determine aesthetic or functional problems that vary according to different locations. Radiographically, osteomas appear as radiopaque lesions similar to bone cortex, and may determine bone expansion. Cone beam CT is the optimal imaging modality for assessing the relationship between osteomas and adjacent structures, and for surgical planning. The differential diagnosis includes several inflammatory and tumoral pathologies, but the typical craniofacial location may aid in the diagnosis. Due to the benign nature of osteomas, surgical treatment is limited to symptomatic lesions. Radical surgical resection is the gold standard therapy; it is based on a minimally invasive surgical approach with the aim of achieving an optimal cosmetic result. Reconstructive surgery for an osteoma is quite infrequent and reserved for patients with large central osteomas, such as big mandibular or maxillary lesions. In this regard, computer-assisted surgery guarantees better outcomes, providing the possibility of preoperative simulation of demolitive and reconstructive surgery.
\end{abstract}

Keywords: osteoma; bone neoplasms; oral surgery; computed tomography; radiography

\section{Introduction and Pathogenesis}

An osteoma is a benign lesion characterized by the presence of both cortical and cancellous bone tissue. Its onset is almost exclusively in the craniofacial area [1-6].

Depending on the site, three subtypes of osteomas are distinguished:

- Central, characterized by progressive endosseous development, eventually resulting in the complete replacement of the affected bone segment (Figure 1);

- $\quad$ Peripheral, consisting of periosteal development that can appear as a pedunculated mass (Figure 2);

- Extraosseous, which develops within the soft tissues, particularly in the muscles [2].

The pathogenesis of osteomas is still under debate, and different onset sites are described in the literature, such as the frontoethmoidal junction or the temporal bone, where osteomas can be associated with congenital cholesteatoma [7,8]. For this reason, some authors consider osteomas to be congenital lesions, arising from an embryonal cartilaginous rest or a persistent embryological periosteum [9]. The association of osteomas with colonic diseases such as Gardner's syndrome suggests a possible hereditary nature [10]. On the other hand, some of the most frequent osteoma onset locations are susceptible to trauma (e.g., to the frontal bone or to the angle and lower border of the mandible), suggesting that previous trauma may contribute to the development of these tumors [11]. 


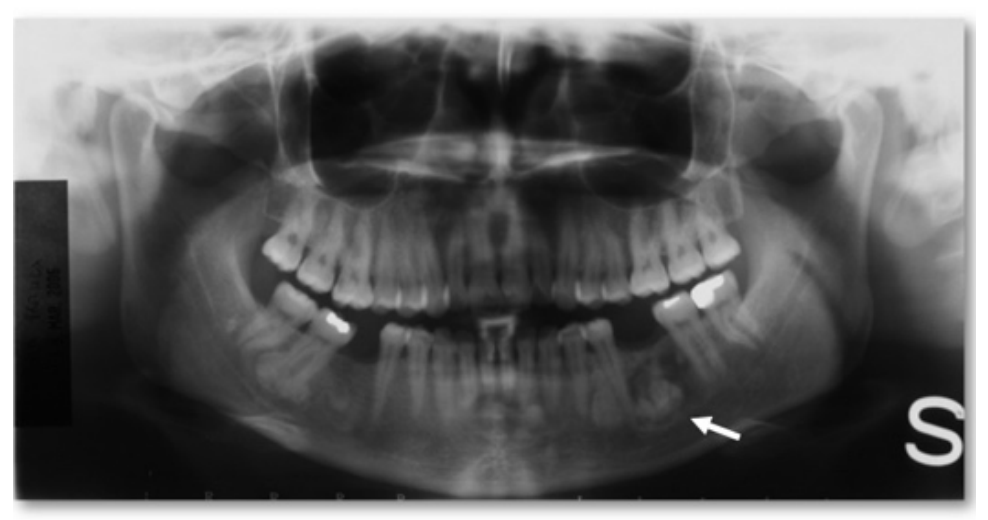

Figure 1. Central osteoma: panoramic radiograph showing a localized, well-defined radiopacity involving the alveolar bone of the left mandibular body (white arrow). The finding was incidental, and the patient did not refer to any symptoms.

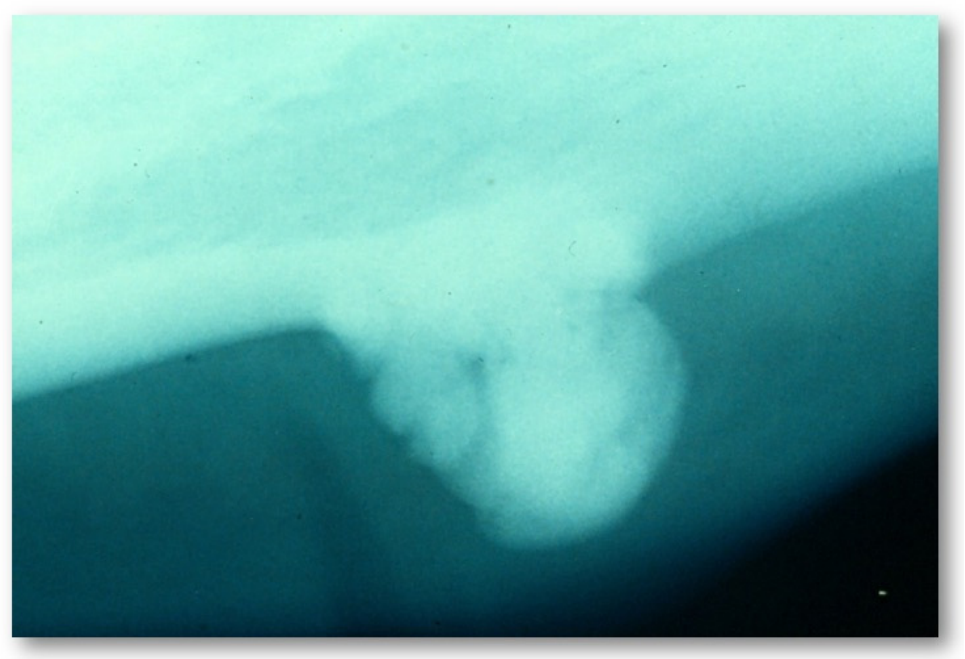

Figure 2. Plain radiography showing a peripheral osteoma involving the mandibular body.

Osteomas exhibit continuous growth rather than growth cessation. This characteristic is the major feature distinguishing them from other bony exostoses such as tori, which are non-pathological protuberances arising from cortical bone with a wide attachment base, usually found in the oral region or, less frequently, in the auditory canal or maxilla [12]. Oral tori are classified according to the onset site, as in torus palatinus and torus mandibularis; the first occurs along the midline of the palate, while the second is often bilateral and is located on the lingual side of the mandible, in the canine or premolar region above the attachment of the mylohyoid muscle [12]. Moreover, while osteomas show a focal implant on the bone, tori have diffuse attachments. Osteomas' slow growth rate can become faster in cases of osteogenesis rate increases [4]. As they are frequently small and asymptomatic, it is difficult to precisely define osteomas' exact incidence, which is estimated to be from 0.002 to $3 \%$, with a predilection for occurring in young males (15-30 years) [13].

\section{Histological Findings}

Histologically, an osteoma is represented as a mass of abnormal dense bone that may originate from the periosteum or from bone marrow, thus differentiating between two types of osteomas [1,2]. Compact osteomas, also called "ivory", are made of mature lamellar bone with minimal marrow spaces and occasional haversian canals without any fibrous structure [3,4] (Figure 3). On the other hand, trabecular osteomas, also called "mature", are composed of cancellous trabecular bone with bone marrow enclosed by a cortical bone 
margin [5]. This distinction is typical of all osteomas and does not involve any association with a pattern of tumor proliferation.

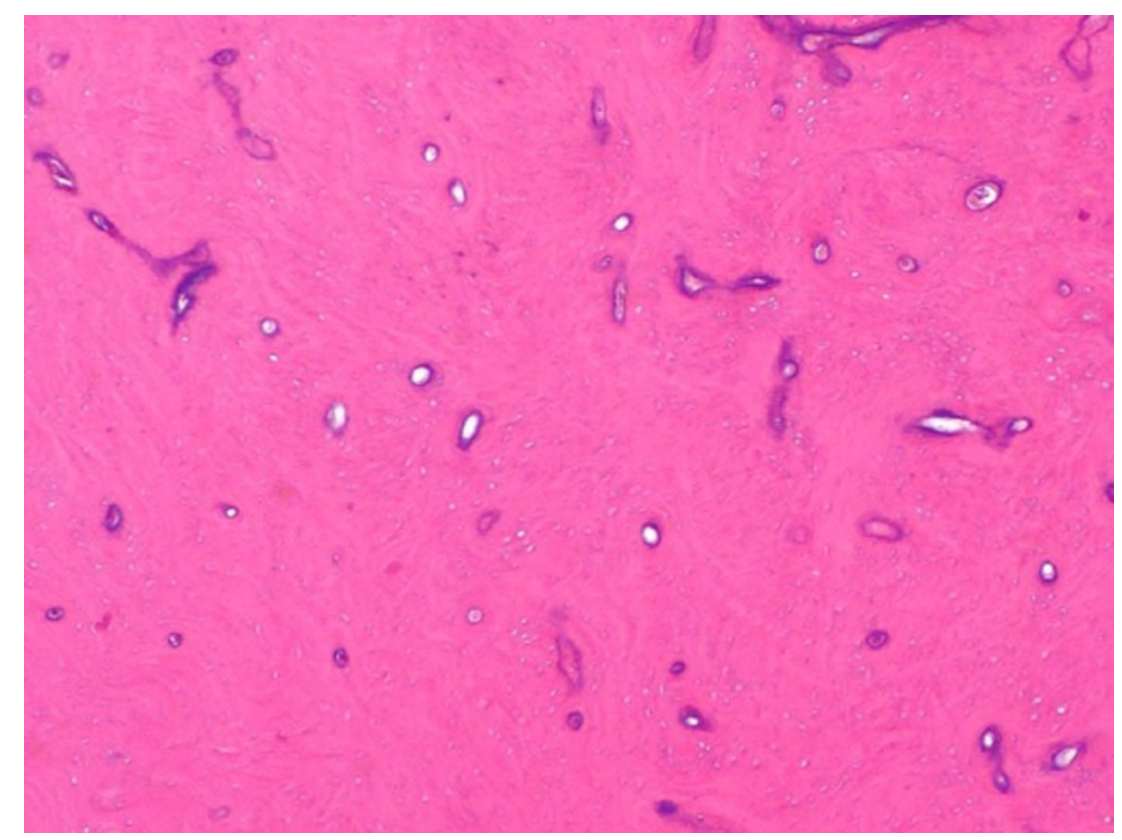

Figure 3. Microscopic view (hematoxylin-eosin staining $\times 40$ ) of a maxillary sinus osteoma. The following features are observed: multiple areas of compact lamellar bone deposition and proliferation of irregular trabeculae, with few osteons and minimal marrow spaces.

The theory of "zonation of histology" is cited in some studies, describing two different areas within osteomas: a fibrous central area, rich in osteoblasts and blood vessels, actively growing from the center to the periphery, and a peripheral area, less vascularized and metabolically active [14]. This difference could justify a possible partial resection only for the proliferative center of the lesion, preventing its growth, notwithstanding that the literature reports some cases of recurrence only after partial treatment [15].

\section{Clinical Features}

In most cases, osteomas are asymptomatic, and the diagnosis is often made incidentally through radiological investigations conducted for other reasons. More rarely, osteomas can assume significant dimensions causing aesthetic and/or functional problems due to bone distortion, with possible compression of nearby structures (Figure 4). Clinical manifestations of craniofacial osteomas are highly variable according to the sites of onset $[4,14]$, as suggested by multiple case reports described in the literature, the most recent of which we provide for illustrative purposes in Table 1.

The most frequent osteoma onset sites are the jaw and the paranasal sinuses (frontal, ethmoid, maxillary, and sphenoid), followed by the internal and external cranial planking and the maxillary bone [4,15] (Figure 5). 


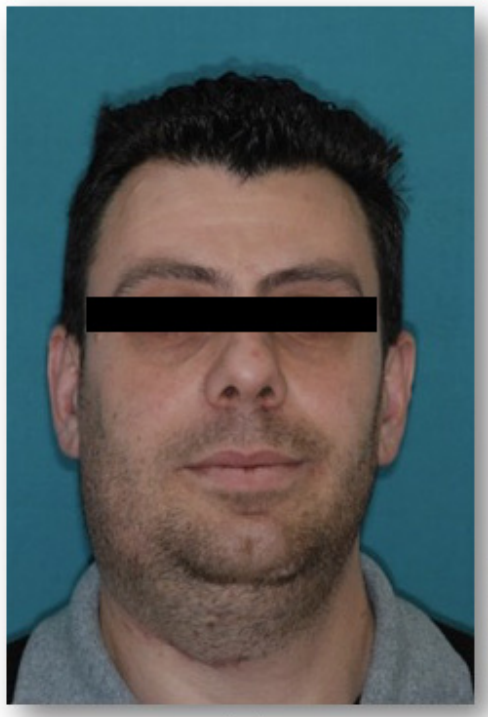

(a)

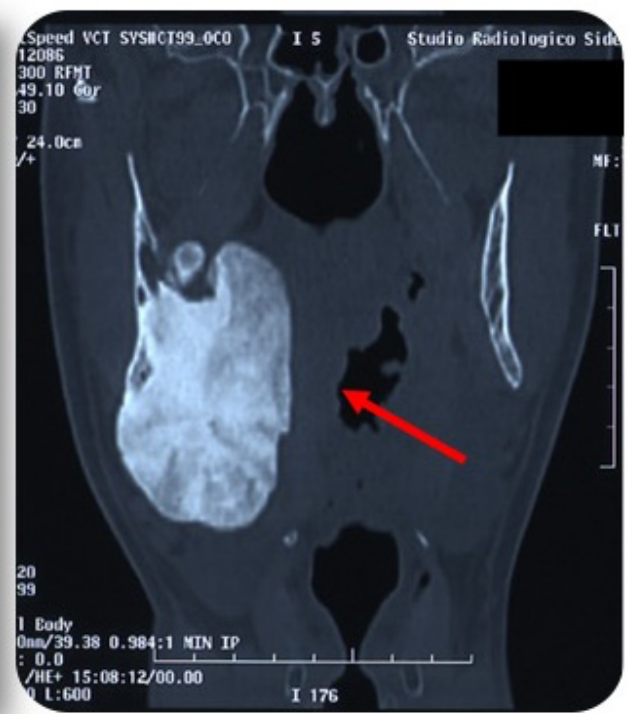

(b)

Figure 4. (a) A young male affected by an extensive right mandibular osteoma, causing facial swelling. (b) Computed tomography (CT) scan shows diffuse enlargement of the entire right mandible, extending to the lateral and medial sides and causing deformation of the pharyngeal walls.

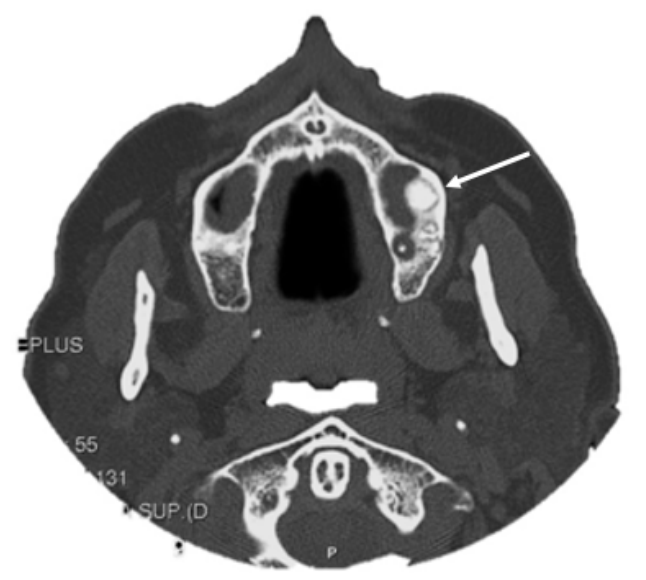

Figure 5. CT scan showing the incidental finding of a small osteoma located in the floor of the left maxillary sinus (white arrow).

In cases of involvement of the paranasal sinuses, an osteoma occupies the ostiomeatal complex, causing an interruption of mucus drainage and airflow, which clinically manifests with sinusitis, pain, headache, and nasal obstruction [4]. The involvement of the midface with an osteoma can sometimes cause facial asymmetry [16-18]; when an osteoma is localized into the orbit, it can cause exophthalmos (Figure 6). 


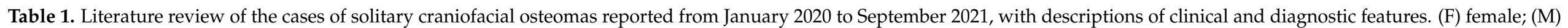
male; (CT) computed tomography; (CBCT) cone beam CT; (XR) radiography; (MRI) magnetic resonance imaging.

\begin{tabular}{|c|c|c|c|c|c|c|c|}
\hline Author & $\begin{array}{l}\mathbf{N}^{\circ} \\
\text { Ref. }\end{array}$ & Patient Gender & Patient Age & $\begin{array}{c}\text { Osteoma } \\
\text { Localization }\end{array}$ & Clinic & Imaging & Comorbidity \\
\hline Ortega Beltrá & [19] & M & 68 & Mandibula & $\begin{array}{l}\text { Ankylosis of the } \\
\text { temporomandibular joint }\end{array}$ & $\mathrm{CT}$ & No \\
\hline Alkhaldi & [20] & M & 44 & $\begin{array}{l}\text { Ethmoid sinus, orbital cavity, } \\
\text { ostium of the maxillary sinus }\end{array}$ & Chronic rhinosinusitis & $\mathrm{CT}$ & $\begin{array}{l}\text { Prior endoscopic } \\
\text { sinus surgery }\end{array}$ \\
\hline Dedushi & [21] & M & 61 & Frontal sinus & $\begin{array}{c}\text { Headaches, generalized } \\
\text { seizures, transient motor } \\
\text { aphasia, regressive } \\
\text { hemiparesis, and } \\
\text { fluctuating blood pressure } \\
\text { values }\end{array}$ & MRI & No \\
\hline Ali & {$[22]$} & M & 35 & Frontal sinus & $\begin{array}{c}\text { Altered } \\
\text { Sensorium }\end{array}$ & CT, MRI & No \\
\hline Mlouka & [23] & M & 26 & Maxillary sinus & Asymptomatic & СВCТ & No \\
\hline Öztürk & [24] & M & 15 & Frontal sinus & Frontal sinusitis & CT & No \\
\hline Benzagmout & [25] & M & 34 & Frontoethmoidal sinus & $\begin{array}{l}\text { Swelling, headaches, } \\
\text { seizures }\end{array}$ & CT, MRI & No \\
\hline Devaraja & [27] & M & 21 & Frontal sinus & $\begin{array}{l}\text { Eyelid swelling and } \\
\text { inability to open the eye }\end{array}$ & $\mathrm{CT}$ & No \\
\hline Nakagawa & [28] & M & 27 & $\begin{array}{l}\text { Frontoethmoidal sinus, } \\
\text { anterior cranial fossa and } \\
\text { orbit, frontal lobe }\end{array}$ & $\begin{array}{l}\text { Headache and generalized } \\
\text { convulsion }\end{array}$ & CT, MRI & No \\
\hline Aksakal & [29] & M & 53 & Frontal sinus & Headache & $\mathrm{CT}$ & No \\
\hline Demircan & {$[30]$} & M & 17 & $\begin{array}{l}\text { Mandibular } \\
\text { ramus }\end{array}$ & Swelling, facial asymmetry & $\mathrm{XR}, \mathrm{CBCT}$ & Prior trauma \\
\hline Azevedo & [31] & M & 30 & $\begin{array}{l}\text { Nasal fossa, the bilateral } \\
\text { ethmoidal cells, and the } \\
\text { frontal } \\
\text { Sinuses }\end{array}$ & Swelling & CT, MRI & Prior trauma \\
\hline
\end{tabular}


Table 1. Cont.

\begin{tabular}{|c|c|c|c|c|c|c|c|}
\hline Author & $\begin{array}{l}\mathbf{N}^{\circ} \\
\text { Ref. }\end{array}$ & Patient Gender & Patient Age & $\begin{array}{c}\text { Osteoma } \\
\text { Localization }\end{array}$ & Clinic & Imaging & Comorbidity \\
\hline Yazici & [32] & $\mathrm{F}$ & 30 & $\begin{array}{l}\text { Frontoethmoidal sinus, } \\
\text { maxillary sinus, middle } \\
\text { concha }\end{array}$ & $\begin{array}{c}\text { Headache, facial pain, and } \\
\text { blurring vision }\end{array}$ & CT & No \\
\hline Kim & {$[33]$} & $\mathrm{F}$ & 39 & Zigomatic bone & Facial swelling & CT & No \\
\hline Chen & {$[34]$} & M & 19 & $\begin{array}{l}\text { Fronto-ethmoid } \\
\text { sinus }\end{array}$ & Diplopia, proptosis & CT & No \\
\hline Hania & [36] & M & 15 & Maxillary sinus & Spontaneous epistaxis & $\mathrm{XR}, \mathrm{CT}$ & No \\
\hline Pathak & [37] & M & 45 & $\begin{array}{l}\text { Fronto-ethmoid } \\
\text { sinus }\end{array}$ & $\begin{array}{l}\text { Change of behavior, } \\
\text { forgetfulness }\end{array}$ & CT, MRI & No \\
\hline Lee & {$[38]$} & $\mathrm{F}$ & 23 & External auditory canal & Aural fullness & CT & No \\
\hline Lee & [38] & M & 19 & External auditory canal & Mild aural fullness & $\mathrm{CT}$ & No \\
\hline Borissova & [39] & $\mathrm{F}$ & 48 & $\begin{array}{l}\text { Retromastoid portion of the } \\
\text { temporal bone }\end{array}$ & Facial swelling & $\mathrm{CBCT}$ & No \\
\hline Temirbekov & [40] & $\mathrm{F}$ & 25 & $\begin{array}{l}\text { Middle ear, mesotympanum, } \\
\text { and hypotympanum }\end{array}$ & $\begin{array}{c}\text { Hearing loss and fullness in } \\
\text { the ear }\end{array}$ & CT & $\begin{array}{l}\text { Prior unilateral } \\
\text { otitis media }\end{array}$ \\
\hline Canzi & {$[41]$} & $\mathrm{F}$ & 64 & $\begin{array}{l}\text { Eustachian tube of the } \\
\text { temporal bone }\end{array}$ & $\begin{array}{l}\text { Progressive bilateral } \\
\text { asymmetric hearing loss }\end{array}$ & CT & No \\
\hline Falcioni & {$[42]$} & $\mathrm{F}$ & 36 & $\begin{array}{c}\text { Middle ear, promontory, } \\
\text { umbus }\end{array}$ & $\begin{array}{c}\text { Progressive monoliteral } \\
\text { hearing loss }\end{array}$ & $\mathrm{CT}$ & No \\
\hline Lee & [43] & M & 24 & $\begin{array}{l}\text { Ethmoid sinus, medial wall } \\
\text { of the orbit }\end{array}$ & $\begin{array}{c}\text { Eye pain, swelling, } \\
\text { decreased vision, purulent } \\
\text { drainage }\end{array}$ & $\mathrm{CT}$ & No \\
\hline Saylisoy & {$[44]$} & $\mathrm{F}$ & 53 & $\begin{array}{l}\text { Eustachian tube of the } \\
\text { temporal bone }\end{array}$ & $\begin{array}{c}\text { Intermittent otalgia and } \\
\text { otorrhea }\end{array}$ & $\mathrm{CT}$ & No \\
\hline Tan & {$[45]$} & $\mathrm{F}$ & 40 & $\begin{array}{l}\text { Temporal bone } \\
\text { (retromastoid) }\end{array}$ & Swelling behind the ear & $\mathrm{CT}$ & No \\
\hline Nilesh & [46] & $\mathrm{F}$ & 65 & Mandibular condyle & Limited mouth opening & $\mathrm{XR}, \mathrm{CT}$ & No \\
\hline Ghita & [47] & $\mathrm{F}$ & 25 & $\begin{array}{l}\text { Posterior } \\
\text { mandible }\end{array}$ & Facial swelling & $\mathrm{XR}, \mathrm{CBCT}$ & No \\
\hline
\end{tabular}


Table 1. Cont

\begin{tabular}{|c|c|c|c|c|c|c|c|}
\hline Author & $\begin{array}{l}\mathbf{N}^{\circ} \\
\text { Ref. }\end{array}$ & Patient Gender & Patient Age & $\begin{array}{c}\text { Osteoma } \\
\text { Localization }\end{array}$ & Clinic & Imaging & Comorbidity \\
\hline Kayaci & [48] & $\mathrm{F}$ & 80 & $\begin{array}{l}\text { Posterolateral wall of the } \\
\text { lesser wing of the sphenoid } \\
\text { bone }\end{array}$ & Vision loss, pain, headache & $\mathrm{CT}$ & No \\
\hline Torres & [49] & M & 21 & $\begin{array}{l}\text { Posterior } \\
\text { mandible }\end{array}$ & Facial swelling & $\mathrm{CT}$ & No \\
\hline Nayak & [50] & M & 30 & $\begin{array}{l}\text { Posterior } \\
\text { mandible }\end{array}$ & $\begin{array}{l}\text { Swelling in the lower left } \\
\text { back tooth region }\end{array}$ & $\mathrm{XR}$ & No \\
\hline Lazar & [51] & M & 33 & $\begin{array}{l}\text { Posterior } \\
\text { mandible }\end{array}$ & Swelling, airway deviation & $\mathrm{CT}$ & No \\
\hline Guerra & [52] & M & 25 & $\begin{array}{c}\text { Frontal sinus, ethmoid sinus, } \\
\text { upper and } \\
\text { medial orbital } \\
\text { walls }\end{array}$ & $\begin{array}{c}\text { Double vision, progressive } \\
\text { change in the positioning of } \\
\text { the eye }\end{array}$ & $\mathrm{CT}$ & $\begin{array}{l}\text { Prior orbit } \\
\text { zygomatic } \\
\text { fracture } \\
\text { reconstruction due } \\
\text { to facial trauma }\end{array}$ \\
\hline
\end{tabular}




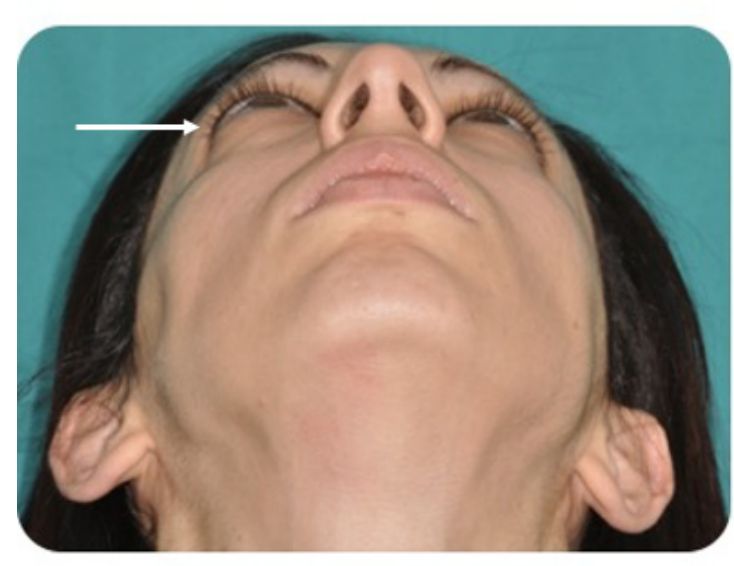

(a)

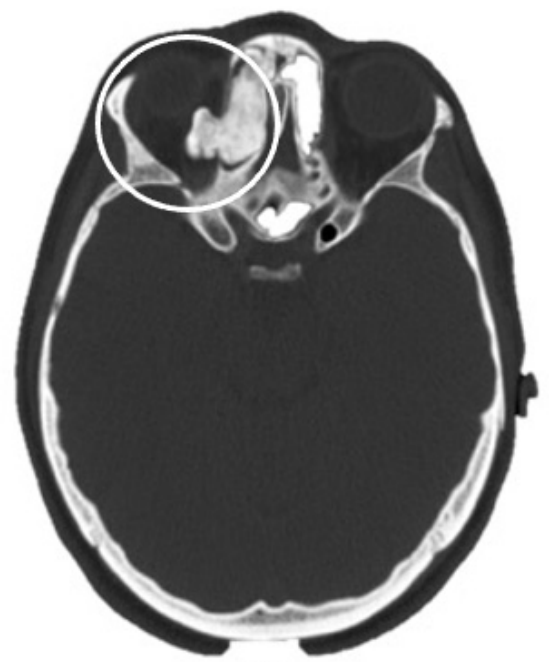

(b)

Figure 6. (a) A young patient presenting right exophthalmos (white arrow) due to an ethmoid osteoma with orbital invasion; (b) CT scan shows an extensive right ethmoid osteoma which invades the orbital cavity (circled in CT scan).

In cases of mandibular condyle involvement, the growth of an osteoma can determine a series of dysfunctions. Specifically, it may cause malocclusion, temporomandibular joint (TMJ) functional impairment, limited mouth opening due to ankylosis, and in some rare cases tinnitus and deafness [45,46] (Figure 7).

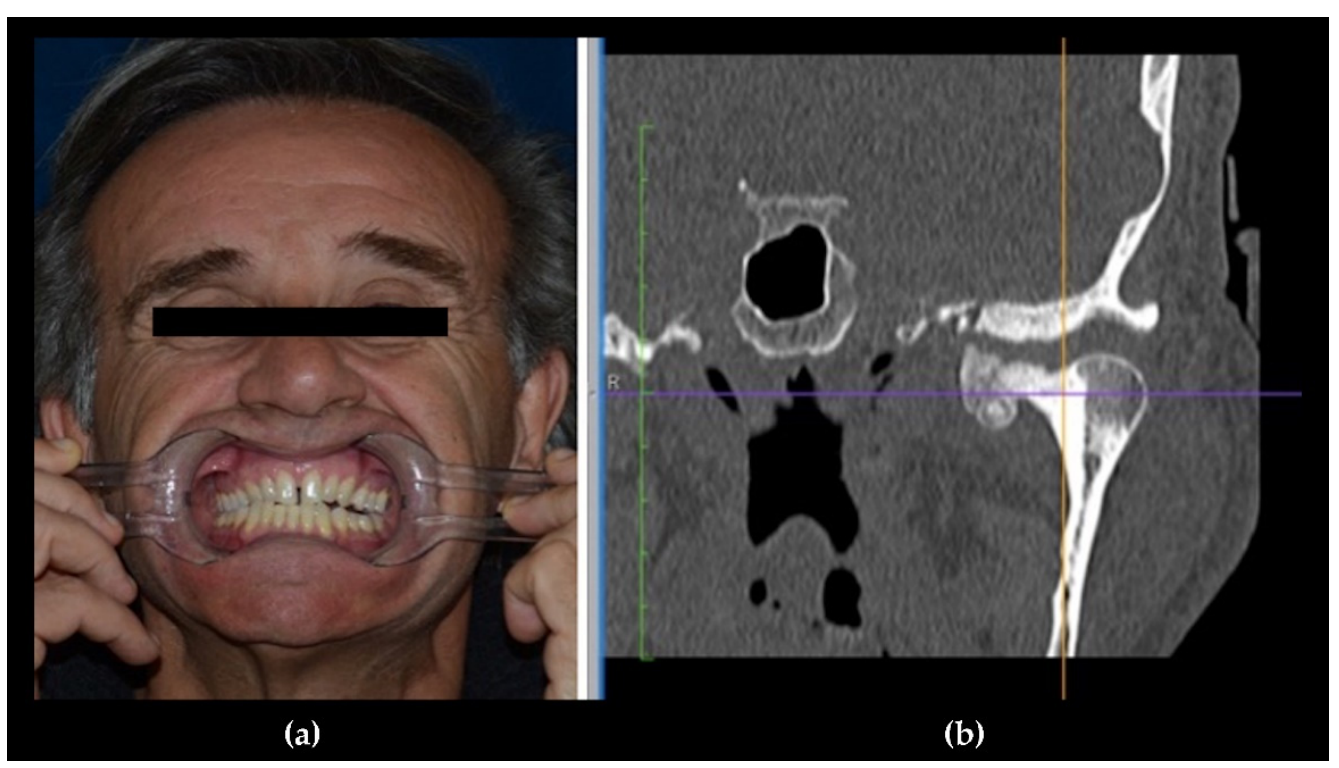

Figure 7. (a) A male patient with dental malocclusion, characterized by left open bite and right cross-bite; (b) CT scan shows a left condylar osteoma.

If multiple facial lesions are present, it is advisable to perform a total body scan by computed tomography (CT), and a colonoscopy to exclude Gardner's syndrome, which is an autosomal dominant autoimmune disease characterized by intestinal polyposis, multiple osteomas, skin fibroids, epidermoid cysts, and the presence of permanent and supernumerary dental elements [53-55]. 


\section{Imaging}

On a CT scan, an osteoma appears as a very radiodense lesion, similar in appearance to normal bone cortex, and mature osteomas may also demonstrate central marrow [56]. Osteomas are usually round or oval, with well-defined and smooth margins, without a perilesional halo [57]. CT is able to better define the epicenter of a bone lesion (medullary, cortical, periosteal, or parosteal) and its behavior in relation to adjacent structures, as a benign or aggressive growth pattern [58]. Specifically, osteomas can eventually determine bone expansion, a peculiarity that can help the differential diagnosis with idiopathic osteosclerosis [59]. In the literature, different $\mathrm{CT}$ findings are described according to the osteoma subtypes, as the ivory type is characterized by very dense bone with some small defined lucent areas, while the mature type shows an uneven bone density mixed with less dense areas, with an appearance similar to fibrous matrix [59,60]. CT is superior to conventional radiography, offering more details about the relationship between the osteoma and the adjacent structures [60]. Moreover, CT studies with 2D and 3D reconstructions provide great support for surgical planning, especially in cases of complex anatomical locations.

The last two decades have seen an increasing importance placed on cone beam computed tomography $(\mathrm{CBCT})$ in diagnosis and treatment planning for maxillofacial district diseases. Smaller physical dimensions, lower costs, and lower radiation doses, when compared to traditional multi-detector CT scans (MDCT), have led to rapid expansion of CBCT scans [61-67]. Recently, technological advancements introduced the concept of dynamic automatic exposure control, in which exposure is adjusted during the acquisition of the image to optimize the radiation dose according to the size and mass of the patient. The doses of ionizing radiation administered by CBCT are generally 5-20 times lower, with the same volume irradiated, when compared to MDCT [68]. In particular, Ludlow et al. [62] compared the effective radiation dose of CBCT with a 64-slice MDCT for oral and maxillofacial imaging, concluding that with a medium field of view (FOV), the CBCT dose ranged from 69 to $560 \mu \mathrm{Sv}$, whereas MDCT produced $860 \mu \mathrm{Sv}$, indicating that the effective dose from a standard dental protocol scan with MDCT was 1.5-12.3 times greater than from a CBCT scan.

CBCT scans can cover a large area of the facial skeleton, overcoming the limits of conventional radiography. Moreover, $\mathrm{CBCT}$ can be reformatted and viewed in multiplanar views (multiplanar reconstruction, or MPR) [66] (Figure 8). CBCT images may be comparable to MDCT images in terms of definition. Currently, neither MDCT nor CBCT can replace magnetic resonance imaging (MRI) for soft tissue evaluation [67]. Newer CBCT scans allow slice thickness to be as low as $0.1 \mathrm{~mm}$, allowing better evaluation of ill-defined margins of bone tumors (e.g., osteomas) for presurgical evaluation or post-surgical follow-up [65]. CBCT images offer acceptably accurate measurements for osseous components, with less than $1 \%$ error when compared to the gold standard of unenhanced CTs of the skull [64-66].

To date, the literature on radiology of the oro-maxillofacial region is mainly represented by case series and transverse or prevalence studies, which do not provide substantial evidence for clinical decision-making; however, many literature reviews agree that $\mathrm{CBCT}$ should be considered as the method of choice for diagnosis of the dento-maxillofacial region [68-72].

A study by Hofmann et al. [73] compared five cone-beam CT (CBCT) scanners and three multi-slice low-dose CT (MSCT) scanners, in evaluating image quality and organ doses. Results proved that image quality was similar among the various systems tested, but they demonstrated distinct differences in organ dose levels. Interestingly, the lowest dose $(0.03 \mathrm{mSv})$ was measured with a CBCT unit and the highest dose $(8.30 \mathrm{mSv})$ with a different $\mathrm{CBCT}$ unit, proving that (depending on the model and setting use) MSCT radiation levels may be even lower than CBCT scan radiation levels. MDCT with optimized low-dose protocols may be considered as an alternative to $\mathrm{CBCT}$ in dento-maxillofacial evaluation, as it guarantees comparable image quality with considerable dose reduction, while also preserving soft-tissue detail $[74,75]$. 


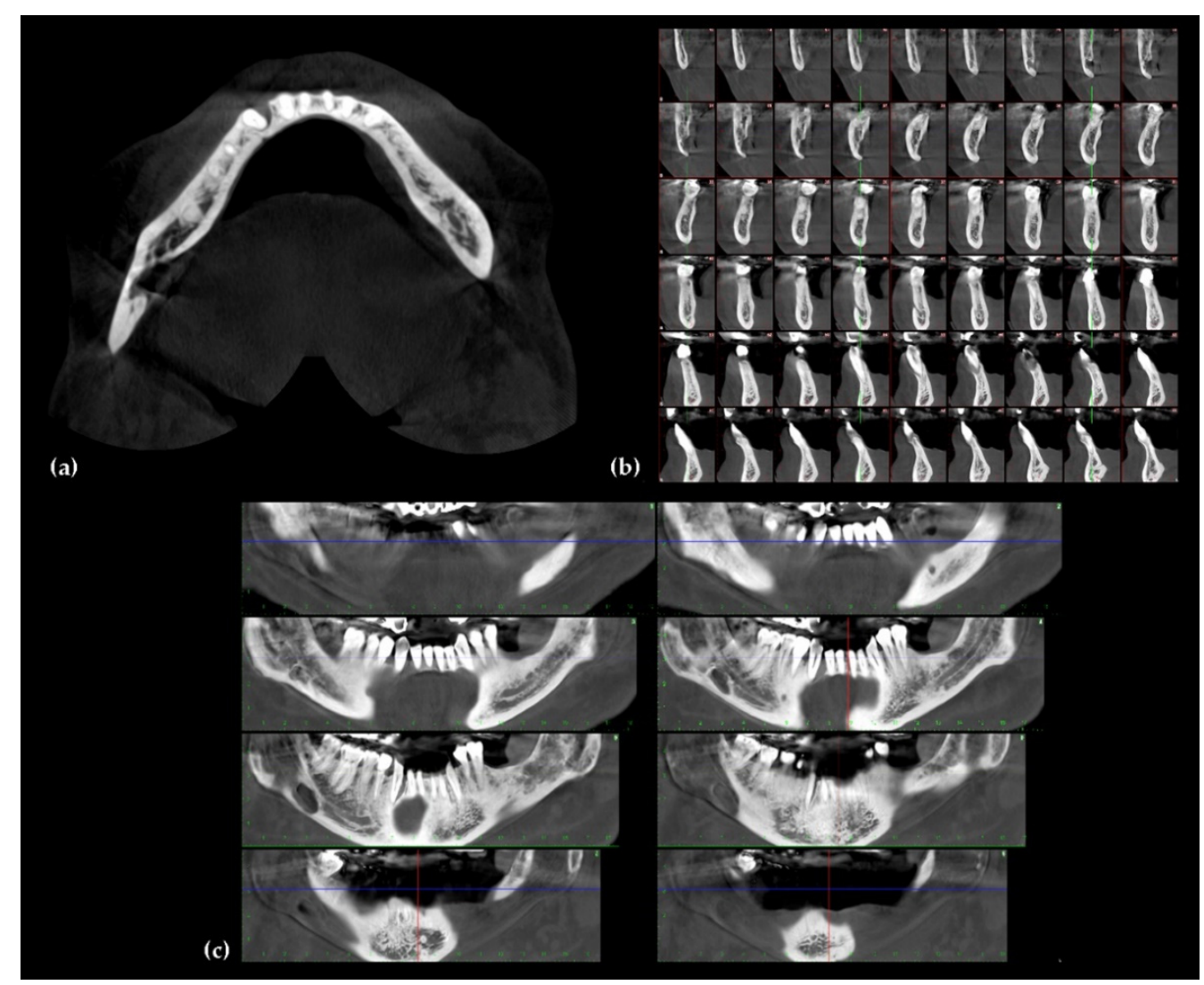

Figure 8. A cone beam computed tomography (CBCT) multiplanar reconstruction of lower jaw: (a) axial view, (b) sagittal view, and (c) coronal view.

The use of MRI in the evaluation of craniofacial osteomas is limited, due to the nature of the lesions. As an osteoma is a dense bone lesion, its evaluation is faster and more effective via CT [57]. Nevertheless, MRI can be used as a supplement to CT in the assessment of adjacent soft tissues and complications associated with an osteoma, such as inflammatory changes in mucosa in the case of an osteoma arising in paranasal sinuses $[21,22,25,28,31,35,37]$.

Integrated 99m Tc-methylene diphosphonate single-photon emission computed tomography (SPECT/CT) is a nuclear medicine study that supplies both functional and anatomical information about the bone, playing a pivotal role as an osteoblastic biomarker for primary bone neoplasms such as osteomas [69]. An osteoma quantitative bone SPECT/CT shows a region of focal radiotracer uptake at the level of the radiodense lesion, providing an accurate functional evaluation of the lesion and supplying anatomical information that can be valuable for diagnosis [76-81]. The Tc-99m bone scintigraphy technique with SPECT/CT can be used as a diagnostic aid in cases of multiple osteomas (as in Gardner syndrome), as it is able to easily identify multiple foci of radiotracer uptake, facilitating detection and simplifying diagnosis [76-82]. Moreover, quantitative bone SPECT/CT can be useful in assessing the biologic growth activity of osteomas, establishing whether a lesion is still actively growing or is relatively inert, which can be helpful in determining the most appropriate management [83,84].

The differential diagnosis of osteomas includes several inflammatory and tumoral pathologies: exostosis, cemento-osseous dysplasia, Paget's disease, chronic focal sclerosing osteomyelitis, osteoblastoma, ossifying fibroma, chondroma, osteosarcoma, fibrous dysplasia, and odontoma $[7,10,85]$. The differential diagnoses for osteomas and osteoblastomas can be challenging, as they are closely related pathologies. In this situation, the anatomical onset sites may be helpful, because osteoblastoma is more common in the jaw and occurs predominantly on the left side of the posterior mandible [85]. Osteoblastomas are usually 
larger in size and exhibit a more rapid rate of growth than osteomas. Radiographically, osteomas appear as radiopaque lesions with a reactive sclerosis of bone and a possible periosteal reaction, while osteoblastomas are radiolucent lesions [57,85].

\section{Surgical Treatment}

Even if there is still no unequivocal consensus, asymptomatic osteomas do not usually require surgery, but rather a "wait and see" strategy based on clinical and radiological follow-up, preferably with CBCT or low-dose MDCT [68-75]. Surgical treatment is only considered in cases of clinical worsening [86,87]. This approach is justified by the fact that osteomas have a slow growth pattern and rarely cause complications, as suggested by their benign nature [11]. Surgical resection is the gold standard treatment. It is based on a radical excision extending to the surrounding normal bone, with the contextual aim of achieving an optimal cosmetic result by choosing the most minimally invasive surgical treatment possible (Figure 9) [88-90].

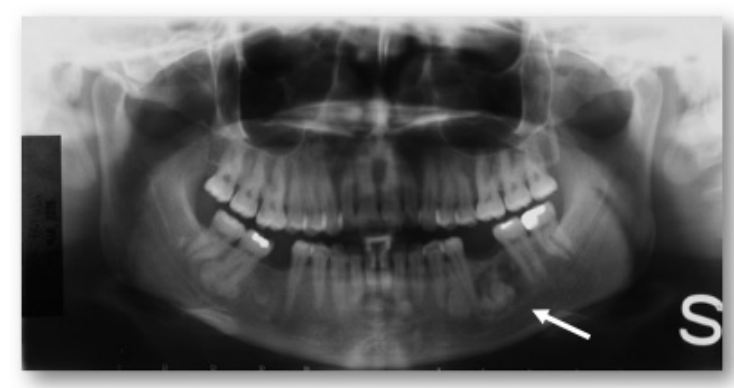

(a)

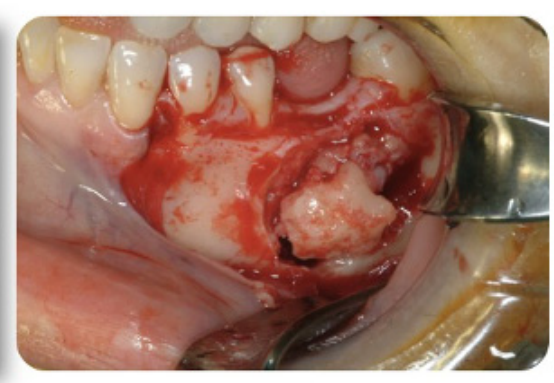

(b)

Figure 9. A case of a mandibular osteoma. (a) The panoramic radiograph demonstrates a focal radiopaque lesion (white arrow); (b) Osteoma's surgical removal via the transoral approach at).

In the case of mandibular osteomas, when only cosmetic changes are required therapy consists of simple lesion excision, while extraoral techniques are limited to bigger osteomas when more extensive exposure is required [91,92].

Larger lesions involving the maxilla may require extensive resective treatment followed by reconstruction with free flaps and/or cad-cam prostheses [86]. Lesions involving the paranasal sinuses can be treated via an endoscopic approach, with en-bloc excisions for lesions of small size and "piecemeal" resections for larger lesions.

In the last decade, computer-assisted surgery for jaw lesions has been demonstrated to achieve better outcomes when compared to traditional techniques [92-94]. This clinical improvement is due to the possibility of preoperative simulation of demolitive and reconstructive surgery. Image-based planning of surgical resection, combined with intraoperative navigation, has exhibited a great potential in the sphere of bone surgery and, in particular, has acquired a pivotal role in oncological cranio-maxillofacial surgery. In fact, pre-operative resection planning can be reproduced intraoperatively using surgical navigation systems that can be extremely precise during surgery, with the aim of better detecting fundamental anatomical structures (e.g., nerves, vessels, and muscles) to enable less demolitive surgical treatment.

In addition, surgical navigation, especially if associated with endoscopy, allows a surgeon to avoid open accesses, thus reducing surgical morbidity. This application is particularly efficient in osteomas in the ethmoid-orbital region (Figure 10). 


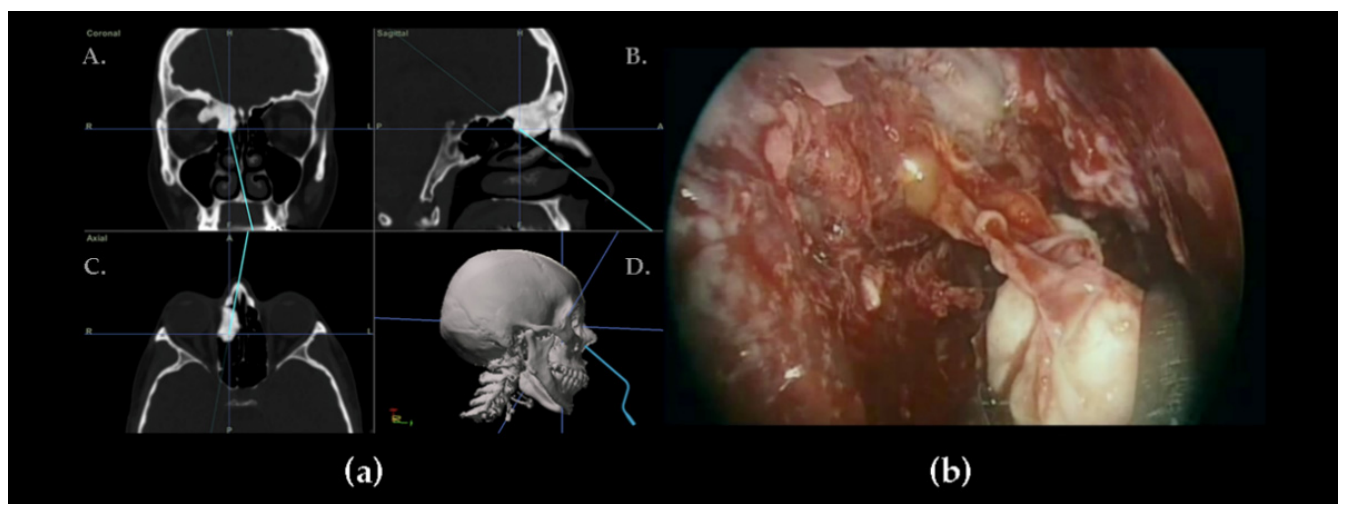

Figure 10. Navigation-guided endoscopic approach for ethmoid-orbital osteoma. (a) Navigation system screenshot showing an osteoma's identification with a navigation pointer: A. coronal view, B. sagittal view, C. axial view, D. 3D reconstruction. (b) Endoscopic view during the osteoma's removal via the trans-nasal approach.

Reconstructive surgery for an osteoma is quite infrequent, and is reserved for patients affected by large central osteomas with big mandibular or maxillary lesions, where reconstructive surgery could be mandatory. Recent medical literature shows that computerassisted design and manufacturing techniques for jaw reconstruction are the best ways of obtaining better aesthetic and functional results $[95,96]$.

\section{Conclusions}

An osteoma is a benign bone craniofacial lesion with a slow growth rate, mainly affecting the mandible. It is usually asymptomatic and detected as an incidental finding in imaging examinations performed for other reasons.

The gold standard imaging modality for investigating osteomas is CT, which can easily identify their "ivory like" appearance, enabling differentiation from other bone diseases in support of pre-surgical analysis. In this regard, the last two decades have seen a significant diffusion of $\mathrm{CBCT}$ in diagnosis and treatment planning of craniofacial osteomas, as it requires a lower radiation dose when compared with conventional MDCT, guarantees optimal spatial definition, and, at the same time, provides multi-planar reconstruction modality for an adequate pre- and post-treatment evaluation.

Treatment is usually performed during an advanced stage of the disease, particularly when an osteoma causes symptoms or functional and aesthetic issues.

Author Contributions: Conceptualization, G.F. and A.T.; methodology, investigation, resources, writing-original draft preparation, G.F., F.R., A.T., A.P., P.S. and A.M.C.; writing-review and editing, A.P., A.M.C. and M.D.C.; supervision, M.M.; project administration, G.F. and A.T.; funding acquisition, G.F. All authors have read and agreed to the published version of the manuscript.

Funding: This research was funded by "Istituto Ortopedico Rizzoli" to cover publication costs.

Institutional Review Board Statement: Not applicable.

Informed Consent Statement: Informed consent was waived because the review used anonymous clinical data and patients were not identifiable in the images.

Data Availability Statement: The data presented in this study are available on request from A.T. and F.R.

Conflicts of Interest: The authors declare no conflict of interest. 


\section{References}

1. Rappaport, J.M.; Attia, E.L. Pneumocephalus in frontal sinus osteoma: A case report. J. Otolaryngol. 1994, 23, 430-436. Available online: https: / / pubmed.ncbi.nlm.nih.gov/7897774/ (accessed on 24 May 2021). [PubMed]

2. Bodner, L.; Gatot, A.; Sion-Vardy, N.; Fliss, D.M. Peripheral osteoma of the mandibular ascending ramus. J. Oral Maxillofac. Surg. 1998, 56, 1446-1449. [CrossRef]

3. Bessho, K.; Murakami, K.I.; Iizuka, T.; Ono, T. Osteoma in mandibular condyle. Int. J. Oral Maxillofac. Surg. 1987, 16, $372-375$. Available online: https:/ / pubmed.ncbi.nlm.nih.gov/3112270/ (accessed on 24 May 2021). [CrossRef]

4. Yamasoba, T.; Harada, T.; Okuno, T.; Nomura, Y. Osteoma of the middle ear: Report of a case. Arch. Otolaryngol. Head Neck Surg. 1990, 116, 1214-1216. [CrossRef]

5. Miller, N.R.; Gray, J.; Snip, R. Giant, mushroom-shaped osteoma of the orbit originating from the maxillary sinus. Am. J. Ophthalmol. 1977, 83, 587-591. [CrossRef]

6. Brucoli, M.; Giarda, M.; Benech, A. Gardner syndrome: Presurgical planning and surgical management of craniomaxillofacial osteomas. J. Craniofac. Surg. 2011, 22, 946-948. Available online: https://pubmed.ncbi.nlm.nih.gov/21558892/ (accessed on 24 May 2021). [CrossRef]

7. Halawi, A.M.; Maley, J.; Robinson, R.; Swenson, C.; Graham, S. Craniofacial osteoma: Clinical presentation and patterns of growth. Am. J. Rhinol. Allergy 2013, 27, 128-133. [CrossRef]

8. Cutilli, B.J.; Quinn, P.D. Traumatically induced peripheral osteoma: Report of a case. Oral Surg. Oral Med. Oral Pathol. 1992, 73, 667-669. [CrossRef]

9. Larrea-Oyarbide, N.; Valmaseda-Castellón, E.; Berini-Aytés, L.; Gay-Escoda, C. Osteomas of the craniofacial region. Review of 106 cases. J. Oral Pathol. Med. 2008, 37, 38-42. Available online: https://pubmed-ncbi-nlm-nih-gov.ezproxy.unibo.it/18154576/ (accessed on 24 May 2021). [CrossRef]

10. Societa' Italiana di Chirurgia Maxillo-Facciale (SICMF). Trattato di Patologia Chirurgica Maxillo-Facciale; Minerva Medica: Torino, Italy, 2007.

11. Ziccardi, V.B.; Smith, J.A.; Braun, T.W. Osteoma of the maxillary antrum. Oral Surg. Oral Med. Oral Pathol. Oral Radiol. Endod. 1995, 80, 378-379. Available online: https:/ / pubmed.ncbi.nlm.nih.gov/8521095/ (accessed on 24 May 2021). [CrossRef]

12. Loukas, M.; Hulsberg, P.; Tubbs, R.S.; Kapos, T.; Wartmann, C.T.; Shaffer, K.; Moxham, B.J. The tori of the mouth and ear: A review. Clin. Anat. 2013, 26, 953-960. [CrossRef]

13. Sayan, N.B.; Üçok, C.; Karasu, H.A.; Günhan, Ö. Peripheral osteoma of the oral and maxillofacial region: A study of 35 new cases. J. Oral Maxillofac. Surg. 2002, 60, 1299-1301. [CrossRef]

14. Chiu, A.G.; Schipor, I.; Cohen, N.A.; Kennedy, D.W.; Palmer, J.N. Surgical decisions in the management of frontal sinus osteomas. Am. J. Rhinol. 2005, 19, 191-197. [CrossRef]

15. Gibson, T.; Walker, F.M. Large osteoma of the frontal sinus. A method of removal to minimise scarring and prevent deformity. $\mathrm{Br}$. J. Plast. Surg. 1951, 4, 210-217. Available online: https://pubmed.ncbi.nlm.nih.gov/14886576/ (accessed on 26 October 2021). [CrossRef]

16. Caufourier, C.; Leprovost, N.; Guillou-Jamard, M.R.; Compère, J.F.; Bénateau, H. Tumeurs bénignes ostéoformatrices du massif craniofacial. Rev. Stomatol. Chir. Maxillofac. 2009, 110, 202-208. Available online: https://pubmed.ncbi.nlm.nih.gov/19660772/ (accessed on 24 May 2021). [CrossRef]

17. Nah, K.S. Osteomas of the craniofacial region. Imaging Sci. Dent. 2011, 41, 107-113. Available online: https://www.ncbi.nlm.nih. gov/pmc/articles/PMC3189534/ (accessed on 24 May 2021). [CrossRef]

18. Kaplan, I.; Calderon, S.; Buchner, A. Peripheral osteoma of the mandible: A study of 10 new cases and analysis of the literature. J. Oral Maxillofac. Surg. 1994, 52, 467-470. [CrossRef]

19. Beltrá, N.O.; Quiles, S.M.; Arroyo, M.M.; Rocher, F.P. Mandibular osteoma as a cause of ankylosis and progressive trismus. BMJ Case Rep. 2021, 14, e244014. [CrossRef] [PubMed]

20. Alkhaldi, A.S.; Alsalamah, S.; Tatwani, T. A case of giant ethmoid sinus osteoma. Cureus 2021, 13. [CrossRef] [PubMed]

21. Dedushi, K.; Hyseni, F.; Musa, J.; Saliaj, K.; Vokshi, V.; Guy, A.; Bhatti, A.; Ahmetgjekaj, I.; Tahir, M.; Shatri, J. Importance of MRI in the diagnosis of a rare intracranial mucocele associated with frontal paranasal osteoma: Case report and literature review. Radiol. Case Rep. 2021, 16, 3094-3098. [CrossRef] [PubMed]

22. Ali, S.; Qasim, A.; Anwar, B.; Choudhary, N.; Akmal, M. Intradural extension of mucocele secondary to giant frontal sinus osteoma: Diagnostic pitfalls. Surg. Neurol. Int. 2021, 12, 1. [CrossRef] [PubMed]

23. Mlouka, M.; Tlili, M.; Hamrouni, A.; Selmi, R.; Khanfir, F.; Khalfi, M.S.; Ben Amor, F. Lateral maxillary sinus floor elevation in the presence of a sinus osteoma: A case report. Clin. Case Rep. 2021, 9, e04124. [CrossRef] [PubMed]

24. Öztürk, N.; Atay, K.; Erkul, B.E.; Karademir, F. A rare case in childhood: Pott's puffy tumor developing secondary to frontal sinus osteoma (Çocukluk Çağında Nadir Bir Olgu: Frontal Sinüs Osteomuna İkincil Pott's Puffy Tümör Gelişimi). Turk. Arch. Pediatr. 2020, 55, 445-448. [CrossRef]

25. Lakhdar, F.; Benzagmout, M.; Chakour, K.; Chaoui, M.E.F. Subdural empyema complicating a giant fronto-ethmoidal osteoma. Asian J. Neurosurg. 2020, 15, 737-740. [CrossRef]

26. Bagheri, A.; Feizi, M.; Jafari, R.; Kanavi, M.R.; Raad, N. Orbital cellulitis secondary to giant Sino-orbital osteoma: A case report. Cancer Rep. 2020, 4, e1296. [CrossRef] [PubMed] 
27. Devaraja, K.; Pujary, K.; Pillai, S. Orbital emphysema secondary to frontal osteoma. J. Craniofacial Surg. 2020, 32 , e353-e355. [CrossRef] [PubMed]

28. Nakagawa, R.; Ima, H.; Yamada, M.; Nishiike, S.; Fujimoto, Y. Intradural mucocele associated with a frontoethmoidal osteoma: A case report. No Shinkei Geka 2020, 48, 691-697. (In Japanese) [CrossRef]

29. Aksakal, C. Frontal recess osteoma causing severe headache. A $\breve{g r}$ 2018, 32, 159-161. [CrossRef]

30. Demircan, S.; Işler, S.C.; Gümüşdal, A.; Genç, B. Orthognathic surgery after mandibular large-volume osteoma treatment. Case Rep. Dent. 2020, 2020, 1-4. [CrossRef]

31. Azevedo, C.; Lima, A.; Filipe, M.A.; Duarte, N.; Dias, L.; Marques, R. Giant post-traumatic frontoethmoid osteoma: Diagnostic, therapeutic and reconstructive approach. Turk. Arch. Otorhinolaryngol. 2020, 58, 61-64. [CrossRef]

32. Yazici, D.; Kuran, G. Giant ethmoid sinus osteoma protruding into the maxillary sinus. J. Craniofacial Surg. 2020, 31, e429-e430. [CrossRef]

33. Kim, J.H.; Choi, J.; Kim, B.K. Peripheral Osteoma of the Zygoma. J. Craniofac. Surg. 2021, Epub ahead of print. [CrossRef][PubMed]

34. Tsai, Y.-J.; Chen, Y.-H. Giant craniofacial osteoma with orbital invasion. Taiwan J. Ophthalmol. 2020, 10, 144-146. [CrossRef]

35. Voicu, I.P.; Bartalena, T. Frontal osteoma-induced headache revealed by conventional radiography with a false negative MRI: Röntgen strikes back. Headache J. Head Face Pain 2020, 60, 615-616. [CrossRef]

36. Hania, M.; Sharif, M.O. Maxillary sinus osteoma: A case report and literature review. J. Orthod. 2020, 47, 240-244. [CrossRef] [PubMed]

37. Pathak, A.; Chaurasia, R.N.; Kumar, A.; Mishra, V.N.; Joshi, D. Frontotemporal dementia: An unusual cause. Int. J. Neurosci. 2019, 130, 736-738. [CrossRef] [PubMed]

38. Lee, K.; Choi, Y.J.; Choi, H.S.; Jeong, J. Spongiotic osteoma in the external auditory canal: Two cases of a rare tumor. SAGE Open Med. Case Rep. 2020, 8, 2050313X20981469. [CrossRef] [PubMed]

39. Borissova, I.B.; Venturin, J.S.; Claro-Woodruff, W.I.; Shintaku, W.H. Mastoid osteoma: A rare incidental finding in an orthodontic patient. Imaging Sci. Dent. 2020, 50, 347-351. [CrossRef]

40. Temirbekov, D.; Celikyurt, C. Middle ear osteoma causing Eustachian tube obstruction: A case report and literature review. J. Otol. 2020, 15, 161-165. [CrossRef] [PubMed]

41. Canzi, P.; Carlotto, E.; Manfrin, M.; Avato, I.; Nardo, M.; Simoncelli, A.M.; Pagella, F.; Benazzo, M.; Matteo, S. Isolated Eustachian tube osteoma: Common lesion in uncommon site. J. Int. Adv. Otol. 2020, 16, 482-484. [CrossRef] [PubMed]

42. Falcioni, M.; Bertoli, G.; Ciavarro, G. An uncommon cause of conductive hearing loss. Am. J. Otolaryngol. 2020, $41,102717$. [CrossRef]

43. Lee, S.; Mallen, J.R.; Ehlers, W.H.; Falcone, T.E. Large ethmoid sinus osteoma presenting as vision threatening orbital abscess. Ear Nose Throat J. 2020. [CrossRef] [PubMed]

44. Saylisoy, S. Multiple osteomas of Eustachian tube causing ipsilateral otitis media. Curr. Med. Imaging 2020, 16, 1052-1054. [CrossRef] [PubMed]

45. Tan, E.W.K.; Barco, J.B.; Rehman, M.U.; Tan, C.C. Retromastoid osteoma-A rare case report. J. Surg. Case Rep. 2020, 2020. [CrossRef] [PubMed]

46. Nilesh, K.; Vande, A.; Reddy, S. Central compact osteoma of mandibular condyle. BMJ Case Rep. 2020, 13, e233082. [CrossRef] [PubMed]

47. Ghita, I.; Brooks, J.K.; Bordener, S.L.; Emmerling, M.R.; Price, J.B.; Younis, R.H. Central compact osteoma of the mandible: Case report featuring unusual radiographic and computed tomographic presentations and brief literature review. J. Stomatol. Oral Maxillofac. Surg. 2020. [CrossRef]

48. Kayaci, S.; Kanat, A.; Seçkin, H. Primary osteoma of the orbit with atypic facial pain: Case report and literature review. Turk. Neurosurg. 2010, 22, 389-392. [CrossRef]

49. Torres, L.H.S.; Filho, J.R.T.C.; Uchôa, C.P.; Neto, R.T.A.; Santos, D.L.P.; Filho, V.A.P. Intrabuccal surgical management of a peripheral mandibular osteoma. J. Craniofacial Surg. 2020, 32, 1952-1953. [CrossRef]

50. Nayak, V.; Rao, P.K.; Kini, R.; Shetty, U. Peripheral osteoma of the mandible. BMJ Case Rep. 2020, 13, e238225. [CrossRef]

51. Lazar, A.; Brookes, C.C. Giant osteomas: Optimizing outcomes through virtual planning-A report of two cases and review of the literature. J. Oral Maxillofac. Surg. 2021, 79, 366-375. [CrossRef]

52. Guerra, R.C.; Carvalho, P.H.D.A.; Pulino, B.D.F.B.; Passetto, M.T.; Junior, J.C.R.; Hochuli-Vieira, E. Maxillofacial manifestation of a giant dimension cranial osteoma. J. Craniofacial Surg. 2020, 31, e538-e539. [CrossRef] [PubMed]

53. Gardner, E.J.; Plenk, H.P. Hereditary pattern for multiple osteomas in a family group. Am. J. Hum. Genet. 1952, 4, 31-36. Available online: https:/ / pubmed.ncbi.nlm.nih.gov /14933371/ (accessed on 24 May 2021).

54. Soni, S.; Bhargava, A. Revisiting peripheral osteoma of the mandible with case series and review of literature. Indian J. Otolaryngol. Head Neck Surg. 2012, 66, 212-218. [CrossRef] [PubMed]

55. Gundewar, S.; Kothari, D.S.; Mokal, N.J.; Ghalme, A. Osteomas of the craniofacial region: A case series and review of literature. Indian J. Plast. Surg. 2013, 46, 479-485. [CrossRef]

56. Woertler, K. Benign bone tumors and tumor-like lesions: Value of cross-sectional imaging. Eur. Radiol. 2003, 13, 1820-1835. Available online: https:/ / pubmed.ncbi.nlm.nih.gov/12700923/ (accessed on 1 August 2021). [CrossRef] [PubMed]

57. Curé, J.K.; Vattoth, S.; Shah, R. Radiopaque jaw lesions: An approach to the differential diagnosis. RadioGraphics 2012, 32, 1909-1925. [CrossRef] 
58. McHugh, J.B.; Mukherji, S.K.; Lucas, D.R. Sino-orbital osteoma: A clinicopathologic study of 45 surgically treated cases with emphasis on tumors with osteoblastoma-like features. Arch. Pathol. Lab. Med. 2009, 133, 1587-1593. Available online: https:/ / pubmed-ncbi-nlm-nih-gov.ezproxy.unibo.it/19792048/ (accessed on 24 May 2021). [CrossRef]

59. Horikawa, F.K.; de Freitas, R.R.; Maciel, F.A.; Gonçalves, A.J. Peripheral osteoma of the maxillofacial region: A study of 10 cases. Braz. J. Otorhinolaryngol. 2012, 78, 38-43. [CrossRef]

60. Angelopoulos, C.; Thomas, S.; Hechler, S.; Parissis, N.; Hlavacek, M. Comparison between digital panoramic radiography and cone-beam computed tomography for the identification of the mandibular canal as part of presurgical dental implant assessment. J. Oral Maxillofac. Surg. 2008, 66, 2130-2135. [CrossRef]

61. Pauwels, R. Cone beam CT for dental and maxillofacial imaging: Dose matters: Table 1. Radiat. Prot. Dosim. 2015, 165, 156-161. [CrossRef]

62. Ludlow, J.B.; Ivanovic, M. Comparative dosimetry of dental CBCT devices and 64-slice CT for oral and maxillofacial radiology. Oral Surg. Oral Med. Oral Pathol. Oral Radiol. Endodontol. 2008, 106, 106-114. [CrossRef] [PubMed]

63. Nardi, C.; Salerno, S.; Molteni, R.; Occhipinti, M.; Grazzini, G.; Norberti, N.; Cordopatri, C.; Colagrande, S. Radiation dose in non-dental cone beam CT applications: A systematic review. Radiol. Med. 2018, 123, 765-777. [CrossRef]

64. Ping, Y.X.; Kun, X.B.; Feng, L.X.; Ling, L.B.; Zhang, F.; Ting, L.J. Value of multi-slice spiral CT with three-dimensional reconstruction in the diagnosis of neoplastic lesions in the jawbones. J. South. Med Univ. 2008, 28, 1700-1702. Available online: https:/ / www.sid.ir/en/Journal/ViewPaper.aspx?ID=150087 (accessed on 14 October 2021).

65. Liang, X.; Jacobs, R.; Hassan, B.; Li, L.; Pauwels, R.; Corpas, L.; Souza, P.C.; Martens, W.; Shahbazian, M.; Alonso, A.; et al. A comparative evaluation of cone beam computed tomography (CBCT) and multi-slice CT (MSCT) Part, I. On subjective image quality. Eur. J. Radiol. 2010, 75, 265-269. Available online: https://pubmed-ncbi-nlm-nih-gov.ezproxy.unibo.it/19410409/ (accessed on 14 October 2021). [CrossRef] [PubMed]

66. Weiss, R.; Read-Fuller, A. Cone beam computed tomography in oral and maxillofacial surgery: An evidence-based review. Dent. J. 2019, 7, 52. [CrossRef] [PubMed]

67. Ludlow, J.B.; Laster, W.S.; See, M.; Bailey, L.J.; Hershey, H.G. Accuracy of measurements of mandibular anatomy in cone beam computed tomography images. Oral Surg. Oral Med. Oral Pathol. Oral Radiol. Endodontol. 2007, 103, 534-542. [CrossRef]

68. Bombeccari, G.P.; Candotto, V.; Gianni, A.B.; Carinci, F.; Spadari, F. Accuracy of the cone beam computed tomography in the detection of bone invasion in patients with oral cancer: A systematic review. Eurasian J. Med. 2019, 51, 298-306. [CrossRef] [PubMed]

69. De Vos, W.; Casselman, J.; Swennen, G. Cone-beam computerized tomography (CBCT) imaging of the oral and maxillofacial region: A systematic review of the literature. Int. J. Oral Maxillofac. Surg. 2009, 38, 609-625. [CrossRef]

70. Horner, K.; Jacobs, R.; Schulze, R. Dental CBCT equipment and performance issues. Radiat. Prot. Dosim. 2012, 153, 212-218. [CrossRef]

71. Patel, S.; Brown, J.; Pimentel, T.; Kelly, R.D.; Abella, F.; Durack, C.; Pimental, T. Cone beam computed tomography in endodonticsA review of the literature. Int. Endod. J. 2019, 52, 1138-1152. [CrossRef]

72. Durack, C.; Patel, S. Cone beam computed tomography in endodontics. Braz. Dent. J. 2012, 23, 179-191. [CrossRef] [PubMed]

73. Hofmann, E.; Schmid, M.; Lell, M.M.; Hirschfelder, U. Cone beam computed tomography and low-dose multislice computed tomography in orthodontics and dentistry. J. Orofac. Orthop. 2014, 75, 384-398. [CrossRef] [PubMed]

74. Widmann, G.; Al-Ekrish, A.A. Ultralow dose MSCT imaging in dental implantology. Open Dent. J. 2018, 12, 87-93. [CrossRef] [PubMed]

75. Loureiro, R.M.; Collin, J.; Sumi, D.V.; Araújo, L.C.; Murakoshi, R.W.; Gomes, R.L.E.; Daniel, M.M. Postoperative CT findings of orthognathic surgery and its complications: A guide for radiologists. J. Neuroradiol. 2021. [CrossRef]

76. Yamamoto, Y.; Nishiyama, Y. SPECT/CT imaging in bone scintigraphy of a case of clavicular osteoma. J. Nucl. Med. Biol. 2014, 2, 73-74.

77. Kitajima, K.; Futani, H.; Komoto, H.; Tsuchitani, T.; Takahashi, Y.; Tachibana, T.; Yamakado, K. Quantitative bone SPECT/CT applications for primary bone neoplasms. Hell. J. Nucl. Med. 2021, 24, 36-44.

78. Enomoto, K.; Nishimura, H.; Hamada, K.; Doi, K.; Kubo, T.; Hatazawa, J. Nuclear imaging of osteoma. Clin. Nucl. Med. 2008, 33, 135-136. Available online: https:/ / pubmed-ncbi-nlm-nih-gov.ezproxy.unibo.it/18209540/ (accessed on 24 May 2021). [CrossRef]

79. Xing, Y.; Zhao, J.; Wang, T. A case of paranasal sinuses osteoma detected on bone SPECT/CT. Clin. Nucl. Med. 2011, 36, 224-226. [CrossRef]

80. Kim, W.H.; Kim, D.-W.; Kim, C.G.; Kim, M.H. Additional detection of multiple osteomas in a patient with Gardner's syndrome by bone SPECT/CT. Nucl. Med. Mol. Imaging 2013, 47, 297-298. [CrossRef]

81. Nojima, K.; Niizuma-Kosaka, F.; Nishii, Y.; Sueishi, K.; Yamakura, D.; Ikumoto, H.; Ohata, H.; Inoue, T. Multidisciplinary treatment of peripheral osteoma arising from mandibular condyle in patient presenting with facial asymmetry. Bull. Tokyo Dent. Coll. 2014, 55, 39-47. [CrossRef]

82. Baykul, T.; Heybeli, N.; Oyar, O.; Doğru, H. Multiple huge osteomas of the mandible causing disfigurement related with Gardner's syndrome: Case report. Auris Nasus Larynx 2003, 30, 447-451. [CrossRef]

83. Shintaku, W.H.; Venturin, J.S.; Langlais, R.P.; Clark, G.T. Imaging modalities to access bony tumors and hyperplasic reactions of the temporomandibular joint. J. Oral Maxillofac. Surg. 2010, 68, 1911-1921. [CrossRef]

84. Noyek, A.; Chapnik, J.; Kirsh, J. Radionuclide bone scan in frontal sinus osteoma. ANZ J. Surg. 1989, 59, 127-132. [CrossRef] 
85. Chattopadhyay, C.P.K.; Chander, M.G.M. Peripheral osteoma of the maxillofacial region diagnosis and management: A study of 106 cases. J. Maxillofac. Oral Surg. 2012, 11, 425-429. Available online: https:/ / pubmed.ncbi.nlm.nih.gov/24293935/ (accessed on 24 May 2021). [CrossRef]

86. Yudoyono, F.; Sidabutar, R.; Dahlan, R.H.; Gill, A.S.; Ompusunggu, S.E.; Arifin, M.Z. Surgical management of giant skull osteomas. Asian J. Neurosurg. 2017, 12, 408-411. [CrossRef]

87. Dell'Aversana Orabona, G.; Salzano, G.; Iaconetta, G.; Piombino, P.; Ponzo, L.; Santella, A.; Astarita, F.; Solari, D.; Salzano, F.A.; Califano, L. Facial osteomas: Fourteen cases and a review of literature. Eur. Rev. Med. Pharmacol. Sci. 2015, 19, 1796-1802. Available online: https:/ / pubmed.ncbi.nlm.nih.gov/26044223/ (accessed on 24 May 2021).

88. Aghabeigi, B.; Evans, A.; Crean, S.J.; Hopper, C. Simultaneous repair of an orbital floor fracture and removal of an ethmoid osteoma: Case report and review of the literature. Int. J. Oral Maxillofac. Surg. 2003, 32, 94-96. [CrossRef]

89. Swanson, K.S.; Guttu, R.L.; Miller, M.E. Gigantic osteoma of the mandible: Report of a case. J. Oral Maxillofac. Surg. 1992, 50, 635-638. [CrossRef]

90. Tarsitano, A.; Marchetti, C. Presentazione atipica di una sindrome delle apnee ostruttive notturne causata da un osteoma gigante della mandibola: Presentazione del caso e revisione della letteratura. Acta Otorhinolaryngol. Ital. 2013, 33, 63-66. Available online: http:/ / www.ncbi.nlm.nih.gov / pubmed/23620643\%0Ahttp:/ / www.pubmedcentral.nih.gov/articlerender.fcgi?artid= PMC3631812 (accessed on 24 May 2021).

91. Longo, F.; Califano, L.; De Maria, G.; Ciccarelli, R. Solitary osteoma of the mandibular ramus: Report of a case. J. Oral Maxillofac. Surg. 2001, 59, 698-700. [CrossRef]

92. Tarsitano, A.; Battaglia, S.; Ricotta, F.; Bortolani, B.; Cercenelli, L.; Marcelli, E.; Cipriani, R.; Marchetti, C. Accuracy of CAD/CAM mandibular reconstruction: A three-dimensional, fully virtual outcome evaluation method. J. Cranio-Maxillofac. Surg. 2018, 46, 1121-1125. [CrossRef]

93. Ricotta, F.; Cercenelli, L.; Battaglia, S.; Bortolani, B.; Savastio, G.; Marcelli, E.; Marchetti, C.; Tarsitano, A. Navigation-guided resection of maxillary tumors: Can a new volumetric virtual planning method improve outcomes in terms of control of resection margins? J. Cranio-Maxillofac. Surg. 2018, 46, 2240-2247. Available online: https:// pubmed-ncbi-nlm-nih-gov.ezproxy.unibo.it/ 30482714/ (accessed on 14 October 2021). [CrossRef]

94. Tarsitano, A.; Ricotta, F.; Baldino, G.; Badiali, G.; Pizzigallo, A.; Ramieri, V.; Cascone, P.; Marchetti, C. Navigation-guided resection of maxillary tumours: The accuracy of computer-assisted surgery in terms of control of resection margins-A feasibility study. $J$. Cranio-Maxillofac. Surg. 2017, 45, 2109-2114. [CrossRef]

95. Ciocca, L.; Marchetti, C.; Mazzoni, S.; Baldissara, P.; Gatto, M.R.A.; Cipriani, R.; Scotti, R.; Tarsitano, A. Accuracy of fibular sectioning and insertion into a rapid-prototyped bone plate, for mandibular reconstruction using CAD-CAM technology. J. Cranio-Maxillofac. Surg. 2015, 43, 28-33. [CrossRef]

96. Tarsitano, A.; Ciocca, L.; Scotti, R.; Marchetti, C. Morphological results of customized microvascular mandibular reconstruction: A comparative study. J. Cranio-Maxillofac. Surg. 2016, 44, 697-702. [CrossRef] 